Natalia Bilousova, representation "Woerwag Pharma GmbH\& Co. KG" (Kyiv, Ukraine) nabel@ua.fm

\title{
АКМЕОЛОГІЧНИЙ ПІДХІД ДО ПРОФЕСІЙНӦ̈ ПІДГОТОВКИ МЕДИЧНИХ ПРЕДСТАВНИКІВ У ВІТЧИЗНЯНИХ ФАРМАЦЕВТИЧНИХ КОМПАНІЯХ
}

\section{AKMEOLOLOGICAL APPROACH TO PROFESSIONAL TRAINING OF MEDICAL REPRESENTATIVES IN DOMESTIC PHARMACEUTICAL COMPANIES}

У статті висвітлюються особливості професійной підготовки медичних представників у вітчизняних фармачевтичних компаніях на основі акмеологічного підходу. Розкривасться суть акмеологічного підходу як системного способу навчання медичних прачівників проектуванню, створенню і частковій апробачї елементів системи професійної діяльності з просування лікарських засобів на фармацевтичному ринку в прочесі взасмодії з його різиими суб' сктами. Він синтезус різиі підходи до професійной діяльності: системний, иілісний, суб́'єктний, синергетичний, аксіологічний. Акцентусться увага на необхідності дотримания акмеологічних закономірностей у виріменні проблеми розвитку професіоналізму медичного представника: вивчення медичним представником або виробничим колективом результативності власної праці; врахування динамічних змін на життсвому иляху людини, пов'язаних з віковими особливостями. Виявлено суттеві відмінності між закономірностями в психологіі розвитку і в акмеології.

Обтрунтована посередницька роль медичного представника, ио дає підстави вважати чю професію складною, оскільки вона потребус медичних і психологічних знань, володіння такими навичками, як: лідерство, наставництво, делегування, уміння мотивувати персонал, володіння акмеологічними знаннями для професійного зростання $i$ розвитку професійної кар 'сри.

Незважаючи на те, иро для розвитку компетентностей медичних представників у фармачевтичних компаніях використовують технологї успіху в галузі професійной діяльності, проте нині актуалізувалась необхідність розроблення науково-методичного забезпечення розвитку кар'єри иих фахівијі, яке має базуватися передусім на акмеологічному підході.

Ключові слова: медичний представник, акмеологічний підхід, акмеологічні закономіриості, фармацевтичиі компанії.

The article highlights the peculiarities of the professional training of medical representatives in domestic pharmaceutical companies on the basis of the acmeological approach. The main point of the acmeological approach as a systematic way of teaching medical workers to the design is revealed, as well as creation and partial testing of elements of the system of professional promotion of medicinal products in the pharmaceutical market in the process of interaction with its various subjects. It synthesizes different approaches to professional activity: systemic, holistic, subjective, synergetic, axiological. The emphasis is on the necessity of adhering to the acmeological laws in solving the problem of the professional development of the medical representative: the study by the medical representative or the production team of the effectiveness of his own work; taking into account the dynamic changes on the human way of life associated with age characteristics. Significant differences between the laws in the developmental psychology and in acmeology are found out. 
The intermediary role of the medical representative is substantiated, which gives reason to consider this profession as complex as it requires medical and psychological knowledge, possession of such skills as: leadership, mentoring, delegation, motivation of personnel, possession of acmeological knowledge for professional growth and development of professional careers.

In conclusion, it is noted that the formation and development of competencies of medical representatives in pharmaceutical companies pay considerable attention to both the technology of success in the field of professional activity. However, they require developed scientific and methodological support for the career development of these specialists, which should be based primarily on the acmeological approach.

Key words: medical representative, acmeological approach, acmeological laws, pharmaceutical companies.

Постановка проблеми. У сучасних закладах медичної вищої освіти не здійснюється цілеспрямована підготовка фахівців 3 означеної професії. До речі треба зауважити, що й найменування такої посади, як “медичний представник”, не передбачено чинним Класифікатором професій ДК 003:2010. Залежно від фактичного кола його обов'язків, у компаніях і зарубіжних представництвах в Україні можуть працювати: “фахівець з маркетингу" (код у Класифікаторі професій - 3439), “фахівець з методів розширення ринку збуту (маркетолог)” (код - 2419.2), “менеджер (управитель) з реклами" (код - 1476.1), “рекламіст" (код - 2419.2) тощо. Проте у практиці діяльності цих фахівців найбільш вживаним $є$ визначення “медичний представник”, як узагальнена назва перелічених вище посад. Їх підготовка, зазвичай, здійснюється безпосередньо на робочому місці у фармацевтичних компаніях, що відповідає принципу безперервності освіти i забезпечує особистісний і професійний розвиток людини, іiї кар'єрне зростання.

Отже, в компаніях, які займаються просуванням ліків на фармацевтичному ринку, передбачається акмеологічний процес 3 використанням певних прийомів $\mathrm{i}$ технологій. Його методологічною основою як інтеграції компетентності, адаптивності і включеності (інклюзіi) та інноваційної творчості в науковій літературі вважається акмеологічний підхід. Він визначається певною ідеєю, концепцією, принципами і базується на основних категоріях. При цьому ключовою є ідея неперервності освіти людини в усі періоди іiі життєдіяльності. У сучасних умовах інтеграції, розвитку світового та європейського просторів освіти і науки, ринку праці актуальність даної проблеми важко переоцінити для фахівців усіх галузей господарювання, у тому числі і фармацевтичної. Її розв'язання сприятиме підвищенню якості професійної підготовки медичних представників на робочому місці, зростанню ефективності виконуваних ними функціональних обов'язків, конкурентоспроможності на ринку праці.

Аналіз останніх досліджень i публікацій. Акмеологія $\epsilon$ предметом дослідження психології $\mathrm{i}$ педагогіки. Сьогодні у доступній базі даних дисертаційних робіт можна знайти наукові праці учених-психологів: О. Блінкова (оптимізація корегувальної діяльності акмеолога кадрової роботи), О. Зобкова (акмеологія саморегуляції навчальної діяльності), Н. Пачиної (акмеологія розвитку поліпрофесійної компетентності), Ю. Курамшина (акмеологія спортивних досягнень), Н. Вишнякової (психологічні основи розвитку креативності в професійній акмеологіi), С. Пожарського (предмет, принципи i методи синергетичної акмеологіi), Н. Джиги (акмеологія створення продуктивного суб’єкта освіти), А. Сучкова (психолого-акмеологічні основи формування готовності організаторів 
муніципальних органів охорони здоров'я до професійної діяльності). Серед українських учених акмеологічним проблемам приділяють увагу учені-педагоги: В. Вакуленко (акмеологічний підхід у теорії і практиці вищої педагогічної освіти України, Білорусі, Росії), Л. Рибалко (акмеологічні засади професійно-педагогічної самореалізації майбутнього вчителя), Н. Ткачова (аксіологічні засади педагогічного процесу в сучасних загальноосвітніх навчальних закладах). Результати аналізу цих праць і низки статей В. Вакуленко, А. Деркач, С. Калашнікової, Н. Лєбєдєвої, Л. Пуховської, Л. Сергєєвої, А. Топузян, Л. Шумельчик та інших учених уможливлює виокремлення проблеми, суголосної із заявленою статтею. Йдеться передусім про те, що залишаються не дослідженими акмеологічні основи професійної діяльності медичних представників, хоча в практиці їхньої діяльності цьому аспекту приділяється значна увага. Наприклад, Ю. Чертков наголошує: "Медичний представник повинен постійно працювати над собою, удосконалюватися як професіонал і як особистість. ... Як правило, наша кар'єрна тактика $\epsilon$ продуктом власного свідомого вибору і базується на талантах, цінностях і принципах, які маємо" [6, с. 409]. Вони покладені в основу особистісного зростання медичного представника та його кар'єри, відносно якої Ю. Чертков зауважує: "Необхідно постійно розвиватися, щоб отримувати більші бонуси i будувати кар'єру” [6, с. 423].

Мета статті полягає у виявленні сутності акмеологічного підходу, акмеологічних закономірностей, їх відмінностями в психологї розвитку i акмеології, визначенні актуальності та особливостей використання акмеологічного підходу в професійній підготовці медичних представників.

Виклад основного матеріалу дослідження 3 повним обгрунтуванням одержаних наукових результатів. У численних наукових працях вітчизняних i зарубіжних учених доведено, що розвиток особистості фахівця не може відбуватися сам по собі, стихійно. I, навіть, організовані тренінги і семінари, воркшопи і коуч-сесії, індивідуальне консультування не вирішують повною мірою проблему розвитку професіоналізму медичного представника, якщо не дотримуватися акмеологічних закономірностей. Йдеться про закономірності “таких способів зв'язку особистості і діяльності, професії і кадрів відповідного профілю, які містять ключ до розв'язання суперечностей між ними, проявляють їх конгруентне, взаємо-оптимальне співвідношення, ведуть до мінімізації психологічних, особистісних, професійних втрат" [3, с. 40]. Відносно цього варто зауважити, що у діяльності фармацевтичних компаній та їх представництв, крім указаних А. Деркач витрат, слід додати економічні і фінансові витрати. На вирішення цісї проблеми спрямовані дослідження в галузі економіки та організації фармацевтичної справи. Прикладом може бути дисертація О. Кухар. Одним 3 результатів його наукової праці 3 оптимізації системи просування лікарських засобів на вітчизняний ринок медичними представниками фармацевтичних компаній стало узагальнення спільних рис та особливостей, позитивних та негативних сторін їхньої роботи. За отриманими результатами дослідник дійшов висновку, що нині виникла необхідність “упровадження нових підходів стосовно адаптації представницького персоналу до умов вітчизняного ринку ...” [4, с. 7].

Практика роботи у вітчизняних компаніях, зарубіжних представництвах свідчить про те, що в них часто застосовується достатньо жорсткий регламент діяльності медичних представників, спостерігається порушення етики взаємодії, висуваються не обгрунтовані вимоги тощо. Відповідно не рідко виникають 
конфліктні ситуації, що призводить до плинності кадрів, а не до отримання очікуваних результатів - зростання продаж. 3 цього питання не тільки українські підприємства та їх представництва, але i представництва зарубіжних фармацевтичних виробництв, очікують науково обгрунтованих рекомендацій щодо організації просування лікарських засобів, які 6 забезпечували не тільки виживання, але i розвиток підприємства, підвищення його конкурентоспроможності, здатності до саморозвитку. Безумовно, провідна роль у цьому належить людському капіталу, а в даному випадку - медичним представникам, підготовкою і розвитком яких займаються в Україні виключно представництва фармацевтичних компаній.

Критично оцінюючи цю діяльність, базуючись на багатолітньому досвіді роботи, вважаємо за необхідне зазначити, що ця функція, зазвичай, покладена на HR-працівників фармацевтичних компаній та їх представництв, які здебільшого використовують послуги тренерських (консалтінгових) компаній (фірм). Цілком очевидно, що ними застосовуються стандартні технології, і не може враховуватися стан просування конкретних лікарських засобів, як й особистісні характеристики i потенціал медичних представників, що працюють в конкретному представництві, закономірності психології та акмеології. Це підтверджує і О. Кухар: "Мало вивченими $є$ взаємовідносини фармацевтичних виробників i посередників, недостатньо уваги приділено організації роботи представництв фармацевтичних фірм, зокрема обгрунтуванню їх участі у вирішенні назрілих проблем охорони здоров'я ..." [4, с. 3].

А. Деркач - один із засновників акмеології як науки порівнює закономірності в психології розвитку i в акмеології та вказує на їх суттєві відмінності: в психології розвитку вони знаходяться у строгій стадіальності і послідовності, а в акмеології за точку відліку беруться дві основні стадії - стартова i фінішна. Зв'язок між ними носить висхідний прогресивний характер, а тому відповідно до визначеної цілі - прогнозуючий, моделюючий, тобто випереджальний. Якщо з позицій психологіi, розвиток - це рух із минулого в майбутнє, то в акмеології - із сьогодення і майбутнього назустріч один одному. На переконання А. Деркача, розвиток в акмеології відповідає двом принципам принципу суперечності і принципу гармонізації, які діють в рамках цілого, системи i не має випадкового, стихійного характеру на відміну від психології [3, с. 41].

У контексті нашого дослідження варто звернути увагу на акмеологічні закономірності, які, хоча і базуються на вже відомих психологічних постулатах, однак у кожному дослідженні виявляються заново і мають конкретний характер. Наприклад, однісю із закономірностей нового мислення, підвищення рівня професіоналізму i продуктивності праці (для медичних представників це збільшення продажів медичних засобів) вважається необхідність вивчення людиною (наприклад, регіональним менеджером) або виробничим колективом результативності власної праці. Ця закономірність відкривається внаслідок конкретного дослідження (є новою); виявляє конкретну функцію нового мислення в професійній діяльності і функцію, яка веде до оптимізації роботи, тобто пов'язана 3 акмеологічними цілями дослідження [там само]. Окрім цього, до закономірностей, що визначають творчу продуктивність, науковці відносять поряд 3 чинниками впливу на розвиток "акме" динамічні зміни на життєвому шляху людини, пов'язані з віковими особливостями (трансформація домінуючих мотивів, еволюція структури інтересів тощо). У зав'язку з цим, підкреслює А. Деркач, 
“предмет акмеологічного дослідження - це не ізольовані самостійні системи, а зв'язки між ними, що відповідають критерію оптимальності" [3, с. 41].

Слід зазначити, що сьогодні найбільш широко використовується акмеологічний підхід у теорії та практиці педагогічної освіти (В. Вакуленко, Л. Петренко, Л. Пуховська, Л. Рибалко, Н. Ткачова та ін.). У ході досліджень ученими встановлено, що “акмеологічний підхід синтезує: системний підхід до професійної педагогічної діяльності; цілісний підхід до вивчення людини як індивіда, особистості, суб'єкта діяльності, індивідуальності, який задає орієнтацію на єдність вивчення й реального вдосконалення майбутнього педагога; синергетичний підхід, який передбачає відкритість освіти, інтеграцію всіх способів освосння людиною світу, включення синергетичних уявлень у процес вищої педагогічної освіти; аксіологічний підхід, що орієнтує педагога на загальнолюдські, національні й професійні цінності, ціннісну спрямованість у педагогічній діяльності" [1, с. 21]. Підсумовуючи, В. Вакуленко узагальнює сутнісну характеристику акмеологічного підходу, яка відображає прагнення до відновлення цілісності суб'єкта. Тому його індивідуальні, особистісні й суб'єктнодіяльнісні характеристики мають вивчатися в усіх взаємозв'язках, щоб сприяти досягненню “акме” - вищих вершин у професійній діяльності. Така точка зору $є$ ідентичною зі сформульованими теоретичними положеннями акмеології в наукових працях А. Деркача.

У контексті нашого дослідження варто зазначити, що сучасний фармацевтичний бізнес має соціальну спрямованість і спирається на принципи соціально-етичного маркетингу для вирішення суспільно значущих запитів. Проте аналізуючи щомісяця результати діяльності (виконання планів продаж), керівники зовнішньої служби з продажу лікарських засобів (філд форс менеджери) увагу акцентують в основному на кількості проданих лікарських засобів через лікарів і аптечні мережі на всій території України, в той час, як необхідно постійно моніторити усі взаємозв'язки медичних представників як посередників між: виробником і лікарем, виробником і працівниками аптек, медичним представником і пацієнтом та звертати увагу на їх характер.

Сьогодні $€$ доведеним, що 70\% медичних представників - це співробітники представництв фармацевтичних компаній, яких називають “дозозалежними”, тобто вони потребують від керівництва індивідуального підходу: чим більше любові, часу і грошей у них вкладе керівництво, тим краще вони працюватимуть. На необхідності враховувати особистісні якості персоналу наголошує Ю. Чертков, зазначаючи, шо, зазвичай, співробітники знаходяться "під впливом стандартів, розроблених офісом. Але, якщо ці стандарти їм не близькі, тоді вони не більш, ніж симпатична роздруківка з логотипом компанії. ...у динамічній фармацевтичній справі, коли кожного дня виникають непередбачувані ситуації “дотримуватися статуту" не завжди легко" [6, с. 41]. Водночас відомий бізнес-теренер погоджується з тим, що прописані стандарти реагування в тих чи інших ситуаціях дійсно надають реальну допомогу. В своєму відомому прикладному курсі успішного медичного представника, як автор низки відомих бестселерів для топменеджерів вітчизняної фармації, він сформулював низку правил формування команд, серед яких - налагодити процес відбору “польових бійців" з відкритого ринку праці (основні проблеми зараз саме з цим компонентом); навчити "бійців" ефективно продавати; озброїти польових “бійців"; призначити "правильних" польових командирів і сформувати правильний штаб [6, с. 428-429]. Через увесь 
зміст цих правил проходить наскрізною стрічкою думка, що медичний представник - це тонка професія, яка потребує медичних і психологічних знань, володіння такими навичками, як: лідерство, наставництво, делегування, уміння мотивувати персонал тощо. На наш погляд, до цього варто додати: володіння акмеологічними і педагогічними знаннями для зростання рівня професіоналізму i розвитку професійної кар'єри.

На необхідності володіння педагогічними здібностями регіональними менеджерами та продакт-менеджерами наголошує також Ю. Чертков. Однак, на нашу думку, доцільно зауважити, що будь-які здібності мають постійно розвиватися. Безумовно, найкращий варіант - це отримання спеціальної педагогічної підготовки, проте сьогодні існування таких освітньо-професійних програм нам не відоме, а тому в фармацевтичних компаніях та їх представництвах суспільні комунікації, освоєння інноваційних форм і методів роботи з персоналом здійснюється здебільшого інтуїтивно без врахування педагогічних закономірностей, які нерозривно пов'язані із закономірностями акмеологічними. Це виходить 3 предмету педагогіки, що визначається як “особлива сфера суспільної діяльності з виховання людини, складовими частинами якої є освіта і навчання" [2, c. 11]. Предметом професійної педагогіки $\epsilon$ "процес формування професійно значимих якостей особистості 3 урахуванням специфічних особливостей професійної освіти того чи іншого рівня і профілю" [5, с. 13]. Для нашого подальшого дослідження важливим є їі положення, відносно того, що процесу освіти (як етапу руху від цілі до результату) має передувати ретельна теоретична i методична розробка системи прийдешньої освітньої діяльності" [5, с. 13]. Ключовим $\epsilon$ слово “система", навіть, якшо йдеться про внутрішньофірмове навчання медичних представників, оскільки в ній мають бути представлені всі компоненти професійної діяльності медичного представника у своєму взаємозв'язку: відповідні освітні стандарти, зміст, методи, засоби, а також організаційні форми навчання і розвитку професіоналізму впродовж усього життя (у разі, якщо людина не змінюватиме свою професію). Принагідно зазначити, що така система має постійно корегуватися у відповідності 3 вимогами часу та потребами суспільства і самої особистості фахівця.

Про необхідність розроблення поетапної технології реалізації медичним представником завдань стосовно просування лікарських засобів, а також робочої програми навчального циклу тематичного удосконалення представників фармацевтичних фірм для оптимізації результативності їхньої роботи йдеться в дисертації О. Кухар [4, с. 9].

Висновки. Під акмеологічним підходом слід розуміти системний спосіб навчання медичних працівників проектуванню, створенню і частковій апробації елементів системи професійної діяльності 3 просування лікарських засобів на фармацевтичному ринку у процесі взаємодії 3 його різними суб'сктами. Він синтезує різні підходи до професійної діяльності: системний, цілісний, суб'єктний, синергетичний, аксіологічний. Професійне навчання медичних представників фармацевтичних компаній i представництв вимагає врахування акмеологічних закономірностей у вирішенні проблеми розвитку їхнього професіоналізму, а саме: вивчення ними або виробничим колективом результативності власної праці; врахування динамічних змін на життєвому шляху людини, пов'язаних 3 віковими особливостями; використання способів зв'язку особистості і діяльності, професії і кадрів відповідного профілю, спрямованих на мінімізацію психологічних, 
особистісних, професійних втрат; прагнення до досягнення цілей або акме; самовдосконалення і саморозвиток упродовж життя. Між закономірностями в психології розвитку і в акмеології існують суттєві відмінності.

Медичний представник виступає посередником між різними суб'єктами фармацевтичного ринку, що дає підстави вважати цю професію складною, оскільки вона потребує медичних і психологічних знань, володіння такими навичками, як: лідерство, наставництво, делегування, уміння мотивувати персонал, володіння акмеологічними знаннями для професійного зростання i розвитку професійної кар'єри.

Не зважаючи на те, що для розвитку компетентностей медичних представників у фармацевтичних компаніях використовують технології успіху в галузі професійної діяльності, проте нині актуалізувалась необхідність розроблення науково-методичного забезпечення розвитку кар'єри цих фахівців, яке має базуватися передусім на акмеологічному підході.

\section{Література}

1. Вакуленко В. М. Акмеологічний підхід у теорії й практиці вищої педагогічної освіти України, Білорусії, Росії (порівняльний аналіз): автореф. дис. ... д-ра пед. наук: 13.00 .01 / В. М. Вакуленко. - Луганськ, 2008. - 46 с.

2. Волкова Н. П. Педагогіка: посіб. для студ. вищ. навч. закладів. / Н. П. Волкова. - Київ: Видав. центр “Академія", 2001. - 576 с. (Альма-матер).

3. Деркач А. А. Логика акмеологического исследования / А. А. Деркач // Вестник РУ ДН. 2004. - № 2. - С. 40-56 (серія "Психология и педагогика").

4. Кухар О. О. Оптимізація системи просування лікарських засобів на вітчизняний ринок: автореф. канд. фарм. наук: 15.00 .01 / О. О. Кухар. - Львів, 2002. - 20 с.

5. Профессиональная педагогика: учебник для студентов, обучающихся по педагогическим специальностям и направлениям / под ред. С.Я. Батышева, А.М. Новикова. - Издание 3-е, переработанное. - М.: Из-во ЭГВЕС, 2009. - 456 с.

6. Чертков Ю. И. Успешный медицинский представитель. Прикладной курс. - Киев: Изд. Дом “Агенство Медицинского Маркетинга", 2014. - 512 с.

\section{References}

1. Vakulenko V. M. Akmeolohichnyi pidkhid u teorii y praktytsi vyshchoi pedahohichnoi osvity Ukrainy, Bilorusii, Rosii (porivnialnyi analiz): avtoref. dys. ... d-ra ped. nauk: 13.00.01/ V. M. Vakulenko. - Luhansk, 2008. - $46 \mathrm{~s}$.

2. Volkova N. P. Pedahohika: posib. dlia stud. vyshch. navch. zakladiv. / N. P. Volkova. - Kyiv: Vydav. tsentr "Akademiia", 2001. - 576 s. (Alma-mater)

3. Derkach A. A. Lohyka akmeolohycheskoho yssledovanyia / A. A. Derkach // Vestnyk RUDN. 2004. - № 2. - S. 40-56 (seriia "Psykholohyia y pedahohyka").

4. Kukhar O. O. Optymizatsiia systemy prosuvannia likarskykh zasobiv na vitchyznianyi rynok: avtoref. kand. farm. nauk: 15.00.01 / O. O. Kukhar. - Lviv, 2002. $-20 \mathrm{~s}$.

5. Professyonalnaia pedahohyka: uchebnyk dlia studentov, obuchaiushchykhsia po pedahohycheskym spetsyalnostiam y napravlenyiam / pod red. S.Ia. Batysheva, A.M. Novykova. - Yzdanye 3-e, pererabotannoe. - M.: Yz-vo ЭHVES, 2009. - $456 \mathrm{~s}$.

6. Chertkov Yu. Y. Uspeshnyi medytsynskyi predstavytel. Prykladnoi kurs. - Kyev: Yzd. Dom "Ahenstvo Medytsynskoho Marketynha", 2014. - 512 s. 